\title{
Comparison between active stress field and tectonic structures in Northern Italy, Lombardy Region
}

\author{
Simona Pierdominici $\left({ }^{1}\right)$, M. Teresa Mariucci $\left({ }^{1}\right)$, Paola Montone $\left({ }^{1}\right)$ and Marco Cesaro $\left({ }^{2}\right)$ \\ (1) Istituto Nazionale di Geofisica e Vulcanologia, Roma, Italy \\ (') Eni SpA, S. Donato Milanese (MI), Italy
}

\begin{abstract}
The aim of this work is to understand the complex pattern of active stress field orientations revealed by borehole breakout analysis with respect to the tectonic structures in a wide region of Northern Italy. The area is located in the central-western part of the Po Plain between the south verging Southern Alps structures and the north verging buried folds and thrusts of the Monferrato and Emilia arcs. Little information concerning the active stress field is available because of the low seismicity level and the thick layer of sediments that covers the entire zone. A detailed borehole breakout analysis has been performed in 36 wells with depths ranging from 2.2 to $7.3 \mathrm{~km}$, whose data have been supplied by Eni. Breakout analysis determined the minimum and maximum horizontal stress directions ( $S_{h \min }$ and $S_{H \max }$ ). The results show a very complex pattern, pointing out that the stress field is not uniform. In this area the regional stress field seems not «strong» enough, compared to the local one, so most of the wells detect only the local field. This work contributes to clarify the various $S_{h \min }$ orientations observed in this area, pointing out at wide scale, a general compression in NNE-SSW direction in this complex region.
\end{abstract}

Key words borehole breakout analysis - active stress field - tectonic structures - Po Plain - Italy

\section{Introduction}

Some contrasting results in terms of $S_{h m i n}$ obtained from the borehole breakout analysis in Lombardy region (Montone et al., 2004), induced us to consider them in more detail to find a possible explanation of data spread. As much literature reports (e.g., Zoback, 1992), borehole breakout analysis is one of the best methods to determine the active stress field in the first 7-8 $\mathrm{km}$ of the earth crust. Usually the orientations

Mailing address: Dr. Simona Pierdominici, Istituto Nazionale di Geofisica e Vulcanologia, Via di Vigna Murata 605, 00143 Roma, Italy; e-mail: pierdominici@ingv.it performed by this technique are coherent with many independent data sets and also are well representative of the regional stress field.

In this work we discuss in situ stress measurements to solve the orientation of active stress field with respect to the tectonic structures. We compare the results with few available data able to provide information on the active stress field, like focal mechanisms of earthquakes, geological and structural data. In fact the seismicity level is quite low and a huge amount of Plio-Quaternary sediments, up to 8 $\mathrm{km}$ thick, hide the structures. We carefully revised 36 deep wells (whose data were kindly supplied by Eni), comparing $S_{h \text { min }}$ orientations with stratigraphy and tectonic units.

We include a brief introduction on the tectonic setting of the area where our deep wells are located, highlighting the presence of active structures and the seismicity pattern. After a short description of the breakout method, we 
proceed to outline in detail the 36 boreholes, from a stratigraphic and tectonic point of view, and the active stress directions inferred for each well. Finally, in the last section we discuss the results and compare them with other available active stress indicators.

\section{Tectonic setting and present-day stress}

The present tectonic setting of Italy is related to the $\sim \mathrm{N}-\mathrm{S}$ convergence between Africa and Europe, complicated by the presence of different geodynamic processes mainly related to: i) the northward indentation of the Adria microplate beneath the Southern Alps; ii) the passive subduction/sinking of the Adria lithosphere beneath the Apennines and the Calabrian Arc; and iii) the Adria microplate rotation with respect to the stable Europe around a pole located, according to some authors, in the western part of the Po Plain (e.g., Anderson and Jackson, 1987; Dewey et al., 1989; Nocquet and Calais, 2003).

The study area is located in the centralwestern part of the Po Plain where the south verging Southern Alps structures face the more external north verging buried folds and thrusts of the Monferrato and Emilia arcs (fig. 1), be- longing to the Apennine structures (Pieri and Groppi, 1981). The Po Plain is a wide flexural basin of about $40000 \mathrm{~km}^{2}$ morphologically flat, gently dipping toward the east, covered by a huge amount of Plio-Quaternary sediments, reaching $8 \mathrm{~km}$ deep east of Emilia Folds, that hide the buried structure geometry (fig. 2). The Plio-Quaternary Apennines tectonic structures are generally referred to different arcs overthrusted towards the north separated by left lateral ramps (Pieri and Groppi, 1981). Their geometry has been defined by oil exploration data performed by Eni both with the interpretation of several hundreds of industrial seismic lines and with the analysis of hundreds of deep wells. On the basis of seismic profile interpretation, according to some authors (Pieri and Groppi, 1981; Castellarin and Vai, 1986; Costa, 2003), the structural arcs seem to have little or no presentday activity and the Plio-Quaternary is almost undeformed. Different models have been proposed to explain the genesis and complex evolution of these buried arcs; for a detailed description of this topic we refer the readers to a recent paper by Costa (2003) and references therein.

Data on active faults in this region are very few. Benedetti et al. (2003) disclosed from geomorphic data the presence of active structures

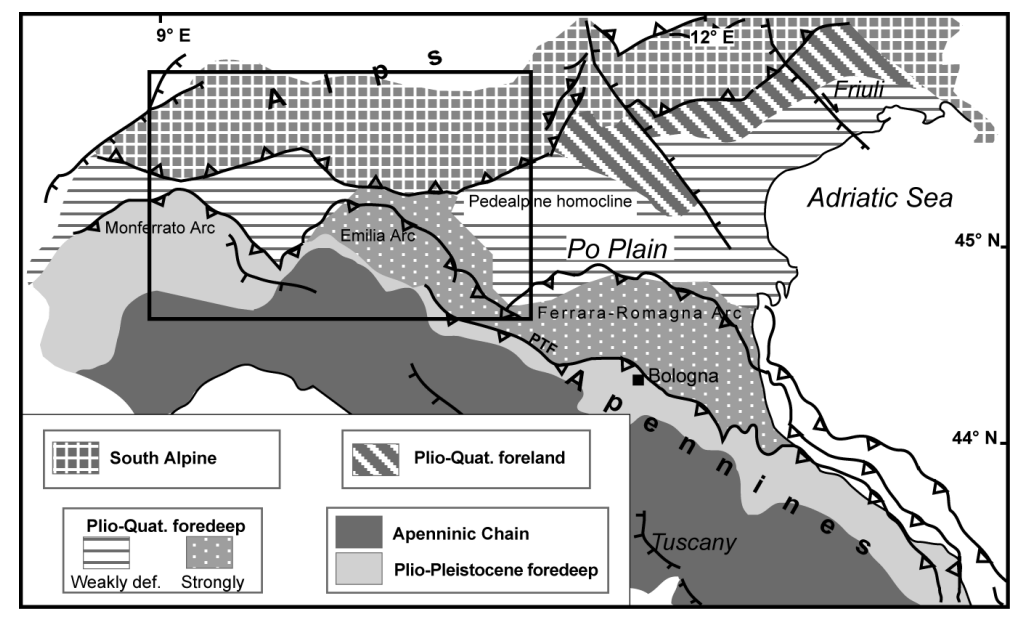

Fig. 1. Simplified tectonic setting of Northern Italy; PTF: pede-Apennine thrust fronts. Modified from CNR (1986). 


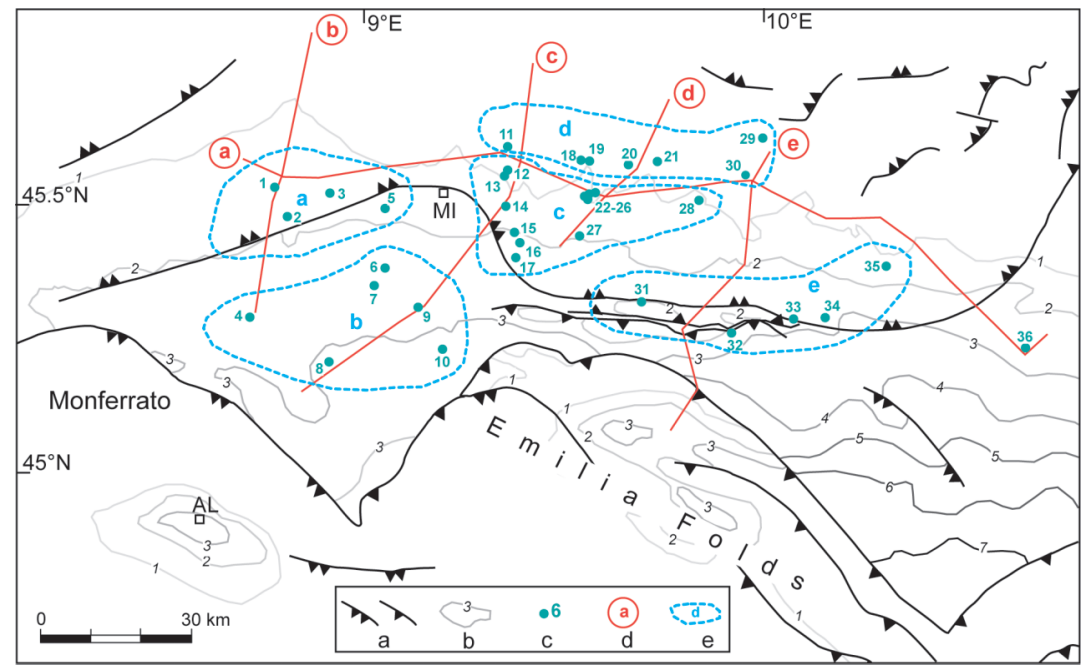

Fig. 2. Location of the 36 study wells. a - Main thrusts; $b$ - isobaths of the base of Pliocene $(\mathrm{km}) ; \mathrm{c}-$ well; $\mathrm{d}-\mathrm{sec}$ tions (see fig. 5a-e); e - groups (see text). Tectonics modified from Pieri and Groppi (1981) and CNR-PFG (1991).

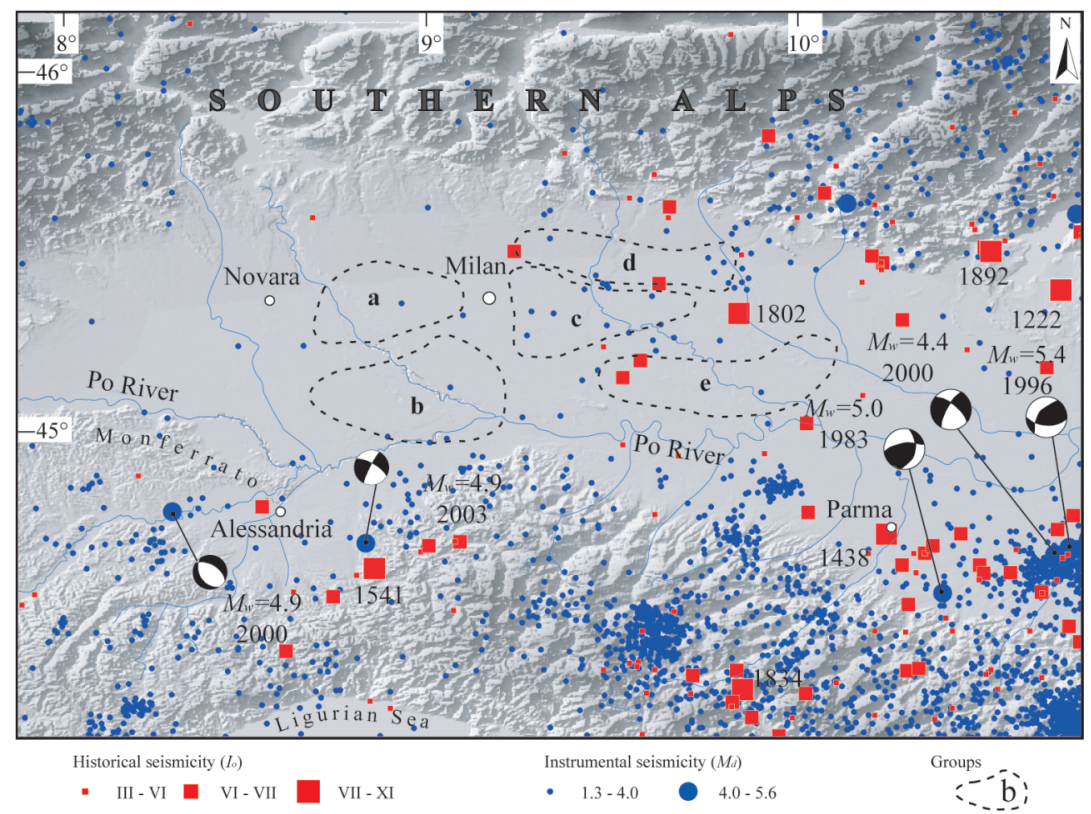

Fig. 3. Seismicity in the study area. Red squares: historical earthquakes from CPTI04 catalogue (Working Group CPTI, 2004); blue dots: instrumental seismicity between 1983-2003 from INGV Bulletin (http://www.ingv.it/ banchedati/banche.html); focal mechanisms from Dziewonski et al. (2000), Selvaggi et al. (2001), Pondrelli et al. (2002) and QRCMT (http://mednet.ingv.it/events/QRCMT/Welcome.html). 
close to Pavia (Emilia Arc): specifically the authors define $\mathrm{a} \sim 35 \mathrm{~km}$ long structure as en échelon cumulative south dipping $\sim \mathrm{E}-\mathrm{W}$ oriented thrust scarp, that cuts Quaternary deposits. The direction of shortening from $\mathrm{N}-\mathrm{S}$ to $\mathrm{N} 15^{\circ} \mathrm{W}$ is compatible with both the E-W thrust and the adjacent NNE-SSW left-lateral ramp (Pieri and Groppi, 1981). Other data located along the Apenninic thrust front (far from the study area), show strike-slip faults and, subordinately, thrust faults with the maximum compression NNW-SSE oriented, on Plio-Pleistocene marine deposits (Perotti, 1991). Moreover, some authors hypothesize shallow E-W oriented seismogenic sources corresponding to blind thrusts (Burrato et al., 2003).

The area is affected by a weak seismicity as documented by historical and instrumental data (fig. 3), even if not far from the studied area seismic events with moderate magnitude occurred. About $100 \mathrm{~km}$ south-east, the most recent ones, the 1983 Parma $\left(M_{w}=5.0\right), 1996$ and 2000 Reggio Emilia $\left(M_{w}=5.4\right.$ and $M_{w}=4.4$, respectively) earthquakes, provide useful information on the active stress field. They are located along the external margin of the active seismic belt and occurred between 10 and $20 \mathrm{~km}$ depth (Selvaggi et al., 2001); all focal mechanisms show a thrust regime with a large strikeslip component and $\sim \mathrm{NW}-\mathrm{SE}$ oriented $P$-axes (Montone et al., 2004). The results of stress inversion from 92 selected fault-plane solutions of the 1996 Reggio Emilia seismic sequence reveal a stress tensor orientation with a $\sim$ sub-horizontal $\sigma_{1} \mathrm{~N}-\mathrm{S}$ directed, an E-W sub-horizontal $\sigma_{2}$, an approximately vertical $\sigma_{3}$ (Selvaggi et al., 2001). About $50 \mathrm{~km}$ south, in the period between 1988 and 1995, a small region was activated with prevailing strike-slip faulting mechanisms (magnitude between 2.5 and 4.8) and sub-horizontal $P$-axes about NE-SW oriented (Frepoli and Amato, 1997; Montone et al., 2004). Moreover, about $100 \mathrm{~km}$ south-west of our area, two seismic events (both with $M_{w}=4.9$ ) occurred in 2000 and 2003 with normal and strike slip faulting mechanisms and NNW-SSE oriented $S_{H \max }$ (Montone et al., 2004). Even though seismicity is relatively far from the area analyzed in this paper, it points out a prevalent active transpressional regime, with $P$-axis NNW-
SSE oriented for the main earthquakes (i.e. Parma and Reggio Emilia) and NE-SW oriented for the smaller seismic sequences. We must also emphasize that the hypocenters of the main events are deeper than $10 \mathrm{~km}$ making the comparison between these data and breakouts (down to $7 \mathrm{~km}$ depth) can be only meaningful to some extent.

Lastly, data on active stress performed by borehole breakout analysis in the Po Plain and surrounding regions come from Montone and Mariucci (1999) and Montone et al. (1999, 2004). From these data, without considering the local variations in $S_{h \min }$ orientations, the authors inferred a main active compression about N-S oriented.

\section{Breakout analysis technique}

Breakout analysis is a method to determine the present stress field (minimum and maximum horizontal stress directions, $S_{h \text { min }}$ and $S_{H \text { max }}$ ) through measurements performed in deep boreholes. When a well is drilled in an anisotropic stress field, the stress concentration, if it exceeds the rock strength, causes borehole enlargements called breakouts. The breakout direction is parallel to the $S_{h \min }$ direction (Bell and Gough, 1979; Plumb and Hickmann, 1985).

The criteria that we use to recognize a breakout zone are those described in Plumb and Hickmann (1985). We use data from four-arm caliper readings, on paper and digital logs, excluding the $\log$ between $0 \mathrm{~m}$ (comparison between active stress field and tectonic structures in Northern Italy, Lombardy Region) and $500 \mathrm{~m}$ depth, in order to avoid possible influences of topographic features on the stress directions at shallow depth (see also Montone and Mariucci, 1999). Data are processed with specific software that allows us to obtain a mean direction with a standard deviation value and a rose diagram scaled by both length and number of breakout zones, for each well. The quality ranking system proposed by Zoback (1992) for the World Stress Map is adopted to attribute a quality value to each well: from «A» quality for the best data, to «E» quality for discarded wells. The quality value is a measure of the statistical distribution of the breakouts depending on total breakout length, standard devia- 
tion of the mean direction, the number of breakout zones. We have also considered the depth and the lithology in which the breakouts are detected.

\section{Data}

The analysis of 36 deep wells, down to about $7 \mathrm{~km}$ depth, shows that only 28 boreholes are useful to determine $S_{h \min }$ direction: 8 wells are classified as «E» (the lowest data quality, no valuable stress indications); 13 are «D», 7 are «C», 6 are $« B »$ and 2 are $» A »($ fig. 4$)$. Table $I$ summarizes the main results and information concerning all the studied wells. Each well in the table has a reference number (see fig. 2 for well location), geographic coordinates, well depth, analysed interval, breakout depth interval, $S_{h \min }$ direction and its standard deviation, breakout length and well quality.
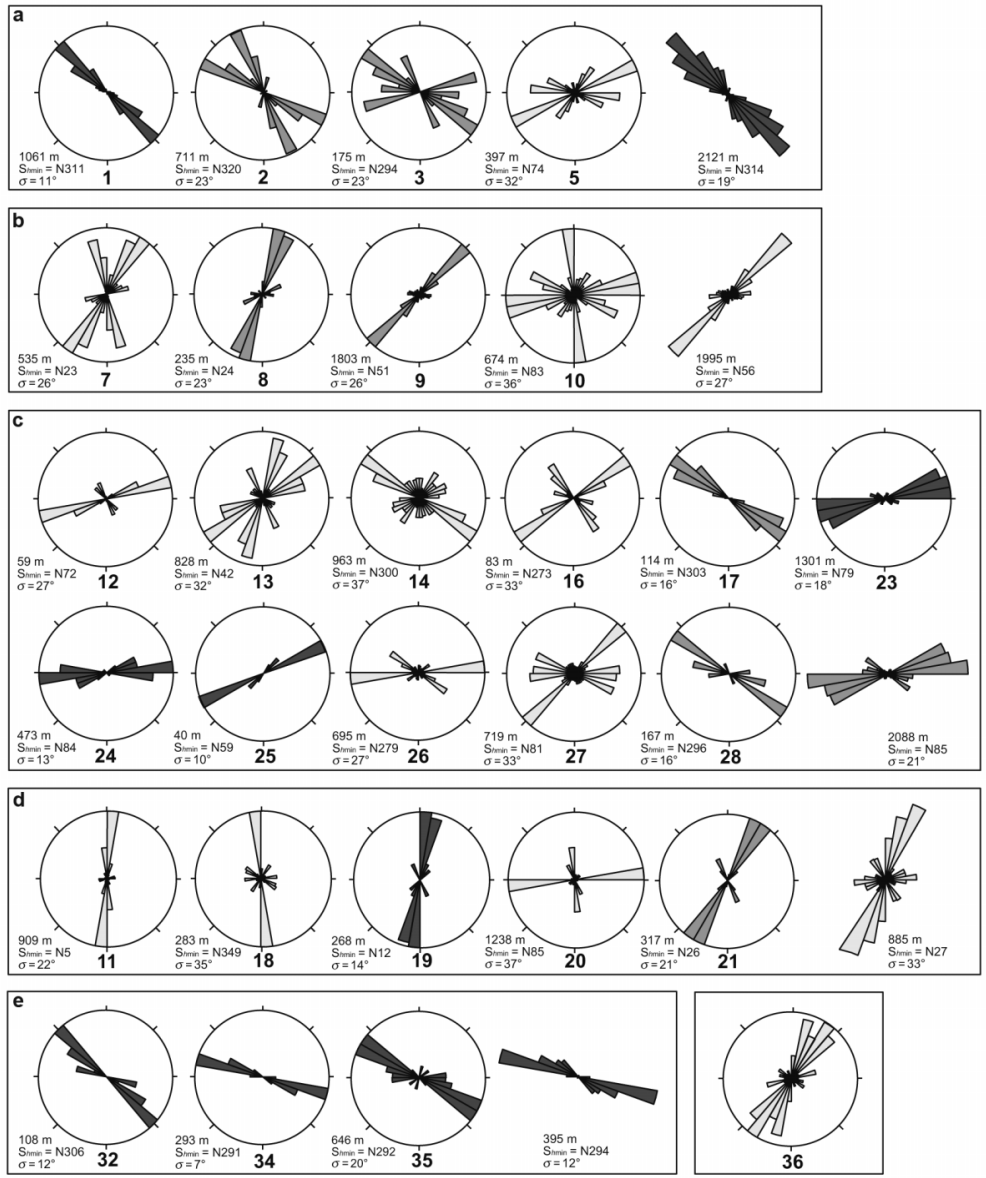

Fig. 4. Breakout analysis results in terms of $S_{h \min }$ orientations. The letters are the groups and the numbers are the wells (see fig. 2). Each rose diagram represents the $S_{h \min }$ direction computed by length for each well. Cumulative rose diagram on the right of each group is computed with breakout data from the best wells (A, B and C quality) of the group. Different grey tones mean the quality ranks (from the best to the lowest quality): dark grey $=\mathrm{A}-\mathrm{B}$, grey $=\mathrm{C}$, light grey $=\mathrm{D}$. Total breakout length and $S_{h \min }$ orientation with its standard deviation are given for each rose plot (see also table I). 
Table I. Borehole breakout data.

\begin{tabular}{|c|c|c|c|c|c|c|c|c|c|}
\hline No. & Lat $^{\circ} \mathrm{N}$ & Long ${ }^{\circ} \mathrm{E}$ & $\begin{array}{l}\text { Well depth } \\
\text { (m) }\end{array}$ & $\begin{array}{c}\text { Analyzed } \\
\text { interval }(\mathrm{m})\end{array}$ & $\begin{array}{c}\text { Breakout } \\
\text { interval }(\mathrm{m})\end{array}$ & $S_{h \min }(\mathrm{N})$ & $\begin{array}{l}\text { s.d. } \\
\pm\end{array}$ & $\begin{array}{c}\text { Breakout } \\
\text { length }(\mathrm{m})\end{array}$ & Qual. \\
\hline 1 & 45.51 & 8.77 & 6560 & $3405-5750$ & $3413-5750$ & $311^{\circ}$ & $11^{\circ}$ & 1061 & B \\
\hline 2 & 45.46 & 8.81 & 4742 & $598-3861$ & $748-3861$ & $320^{\circ}$ & $23^{\circ}$ & 711 & $\mathrm{C}$ \\
\hline 3 & 45.50 & 8.91 & 3576 & $2275-3575$ & $2275-3486$ & $294^{\circ}$ & $23^{\circ}$ & 175 & $\mathrm{C}$ \\
\hline 4 & 45.28 & 8.71 & 5914 & $3254-4501$ & - & - & - & - & $\mathrm{E}$ \\
\hline 5 & 45.48 & 9.05 & 6627 & $1515-6627$ & $1567-6526$ & $074^{\circ}$ & $32^{\circ}$ & 397 & $\mathrm{D}$ \\
\hline 6 & 45.37 & 9.05 & 4965 & $504-4965$ & - & - & - & - & $\mathrm{E}$ \\
\hline 7 & 45.34 & 9.02 & 5338 & $3165-4718$ & $3283-4643$ & $023^{\circ}$ & $26^{\circ}$ & 535 & $\mathrm{D}$ \\
\hline 8 & 45.21 & 8.91 & 6754 & $4925-6530$ & $5603-6000$ & $024^{\circ}$ & $23^{\circ}$ & 235 & $\mathrm{C}$ \\
\hline 9 & 45.30 & 9.13 & 5107 & $501-5090$ & $515-4525$ & $051^{\circ}$ & $26^{\circ}$ & 1803 & $\mathrm{C}$ \\
\hline 10 & 45.23 & 9.19 & 6150 & $1505-4992$ & $1563-4586$ & $083^{\circ}$ & $36^{\circ}$ & 674 & $\mathrm{D}$ \\
\hline 11 & 45.59 & 9.35 & 6264 & $597-5872$ & $1025-5553$ & $005^{\circ}$ & $22^{\circ}$ & 909 & $\mathrm{D}$ \\
\hline 12 & 45.54 & 9.35 & 5030 & 4441-4997 & $4501-4822$ & $072^{\circ}$ & $27^{\circ}$ & 59 & $\mathrm{D}$ \\
\hline 13 & 45.53 & 9.35 & 4507 & $398-4514$ & $1950-4411$ & $042^{\circ}$ & $32^{\circ}$ & 828 & $\mathrm{D}$ \\
\hline 14 & 45.48 & 9.35 & 6042 & $2220-5347$ & $2275-5085$ & $300^{\circ}$ & $37^{\circ}$ & 963 & $\mathrm{D}$ \\
\hline 15 & 45.44 & 9.37 & 2670 & $307-1888$ & $1114-1830$ & $336^{\circ}$ & $35^{\circ}$ & 75 & $\mathrm{E}$ \\
\hline 16 & 45.42 & 9.38 & 2226 & $1283-2223$ & 1761-2081 & $273^{\circ}$ & $33^{\circ}$ & 83 & $\mathrm{D}$ \\
\hline 17 & 45.39 & 9.38 & 2697 & $1508-2697$ & $1705-2467$ & $303^{\circ}$ & $16^{\circ}$ & 114 & $\mathrm{C}$ \\
\hline 18 & 45.56 & 9.54 & 7110 & $300-7100$ & $\begin{array}{c}515-1321 \\
6802-7095\end{array}$ & $349^{\circ}$ & $35^{\circ}$ & 283 & $\mathrm{D}$ \\
\hline 19 & 45.56 & 9.56 & 6500 & $605-2972$ & $650-2920$ & $012^{\circ}$ & $14^{\circ}$ & 268 & B \\
\hline 20 & 45.55 & 9.66 & 6503 & $2689-5110$ & $2700-5058$ & $085^{\circ}$ & $37^{\circ}$ & 1238 & $\mathrm{D}$ \\
\hline 21 & 45.56 & 9.73 & 6910 & $500-6910$ & $3891-5132$ & $026^{\circ}$ & $21^{\circ}$ & 317 & $\mathrm{C}$ \\
\hline 22 & 45.51 & 9.57 & 5927 & $300-5883$ & $\begin{array}{c}510-2350 \\
2710-5790\end{array}$ & $278^{\circ}$ & $38^{\circ}$ & 807 & $\mathrm{E}$ \\
\hline 23 & 45.50 & 9.56 & 5651 & $205-5447$ & $2546-5364$ & $079^{\circ}$ & $18^{\circ}$ & 1301 & B \\
\hline 24 & 45.50 & 9.55 & 5450 & $2491-5326$ & $2500-5305$ & $084^{\circ}$ & $13^{\circ}$ & 473 & A \\
\hline 25 & 45.50 & 9.55 & 5500 & $4754-5398$ & $4771-5140$ & $059^{\circ}$ & $10^{\circ}$ & 40 & B \\
\hline 26 & 45.50 & 9.55 & 5421 & $2490-5417$ & $\begin{array}{l}2547-3550 \\
4809-5409\end{array}$ & $279^{\circ}$ & $27^{\circ}$ & 695 & $\mathrm{D}$ \\
\hline 27 & 45.43 & 9.53 & 2367 & $387-2367$ & $495-2240$ & $081^{\circ}$ & $33^{\circ}$ & 719 & $\mathrm{D}$ \\
\hline 28 & 45.49 & 9.83 & 7267 & $4703-7254$ & $5000-6800$ & $296^{\circ}$ & $16^{\circ}$ & 167 & $\mathrm{C}$ \\
\hline 29 & 45.60 & 9.99 & 3395 & $338-2021$ & $480-1890$ & $005^{\circ}$ & $27^{\circ}$ & 750 & $\mathrm{E}$ \\
\hline 30 & 45.54 & 9.95 & 6840 & $783-6836$ & $790-6700$ & $329^{\circ}$ & $38^{\circ}$ & 1849 & $\mathrm{E}$ \\
\hline 31 & 45.31 & 9.69 & 2600 & $1802-2600$ & $1840-2526$ & $021^{\circ}$ & $29^{\circ}$ & 294 & $\mathrm{E}$ \\
\hline 32 & 45.26 & 9.91 & 2489 & $305-2489$ & $\begin{array}{c}527-1714 \\
2410-2478\end{array}$ & $306^{\circ}$ & $12^{\circ}$ & 108 & B \\
\hline 33 & 45.28 & 10.07 & 2936 & $1494-5325$ & $1494-2793$ & $004^{\circ}$ & $19^{\circ}$ & 113 & $\mathrm{E}$ \\
\hline 34 & 45.28 & 10.15 & 3600 & $402-3502$ & $2840-3252$ & $291^{\circ}$ & $7^{\circ}$ & 293 & A \\
\hline 35 & 45.37 & 10.30 & 6704 & $601-6211$ & $1185-5945$ & $292^{\circ}$ & $20^{\circ}$ & 646 & B \\
\hline 36 & 45.23 & 10.65 & 5312 & $1510-5095$ & $1515-5095$ & $032^{\circ}$ & $28^{\circ}$ & 759 & $\mathrm{D}$ \\
\hline
\end{tabular}




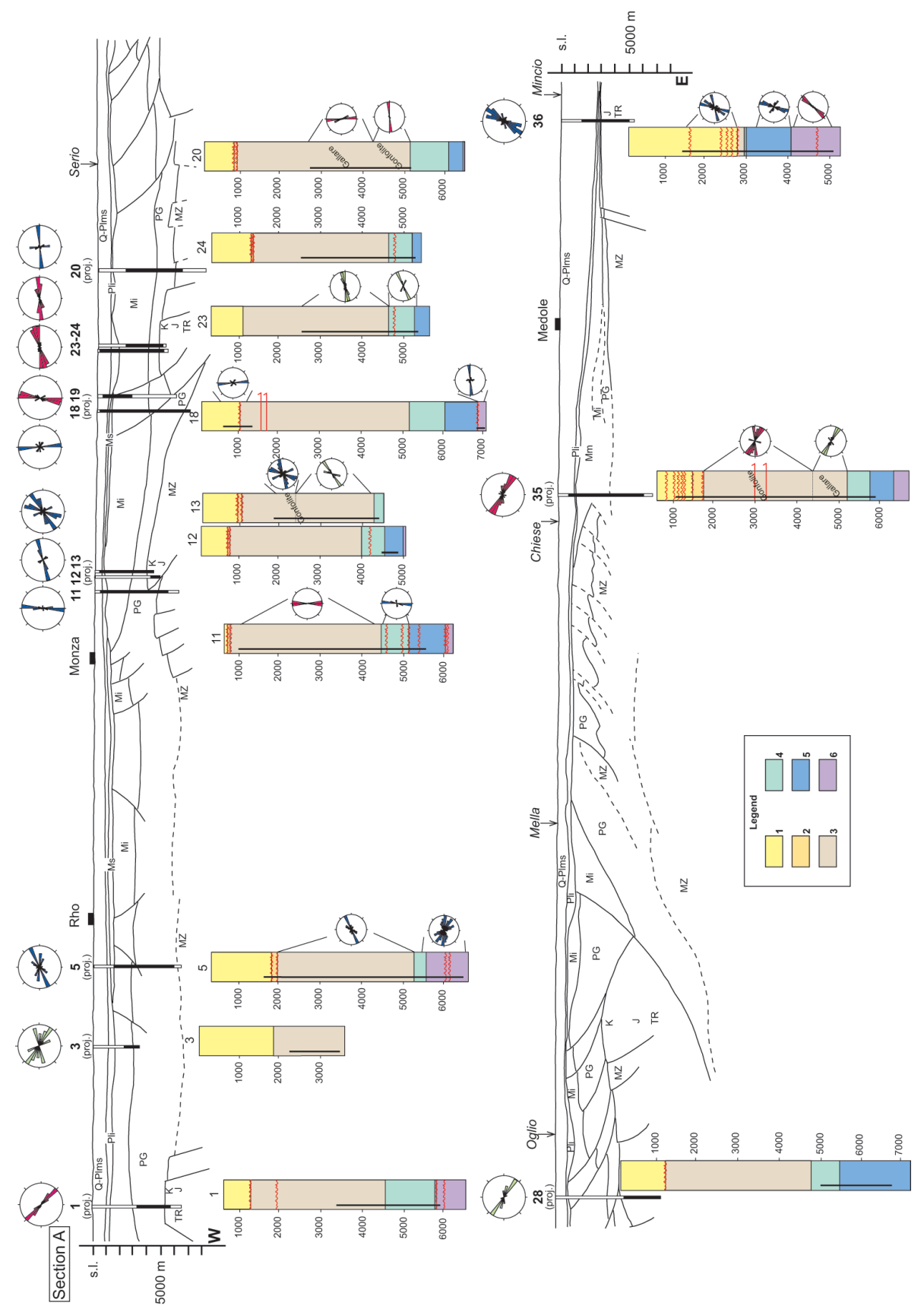

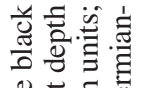

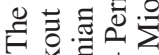

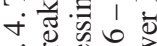

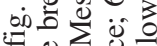

$\Xi \pm$ I

우ㅇㅝㅛ

政它

है Оี

कू क्षे

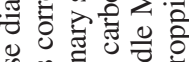

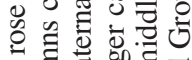

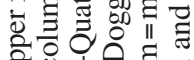

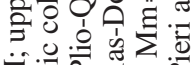

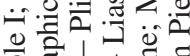

政।

․ㅣㅁ

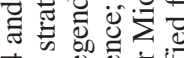

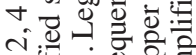

ن.

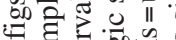

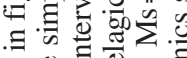

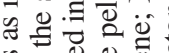

क.

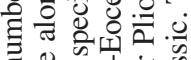

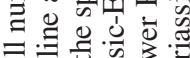

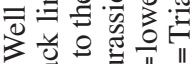

क형

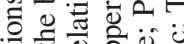

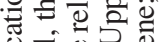

프

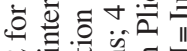

N.

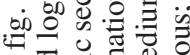

迟

ฮี

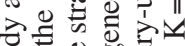

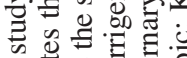

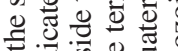

跣券

o 0 है

踏流

.

o o

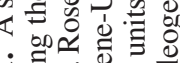

in

in

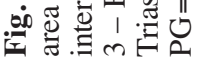


Generally, the Po Plain wells drill the following stratigraphic intervals from top to bottom (fig. 5a-e): Plio-Quaternary clayey-sandy sequence (maximum thickness $2800 \mathrm{~m}$ ), Messinian units (maximum thickness $1100 \mathrm{~m}$ ), EoceneUpper Miocene terrigeneous sequence (Gallare and Gonfolite formations, maximum thickness
$4300 \mathrm{~m}$ ), Upper Jurassic-Eocene pelagic sequence (maximum thickness $1800 \mathrm{~m}$ ), LiasDogger carbonatic sequence (maximum thickness $2100 \mathrm{~m}$ ), and Permo-Trias dolomite and Verrucano deposits (maximum thickness 950 $\mathrm{m})$. The deepest well reaches a depth of $7270 \mathrm{~m}$, the shallowest is $2230 \mathrm{~m}$ deep.

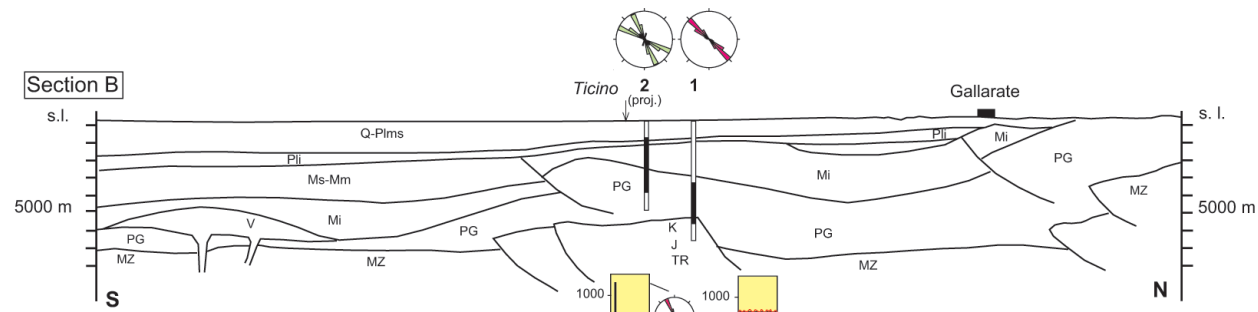

(b)
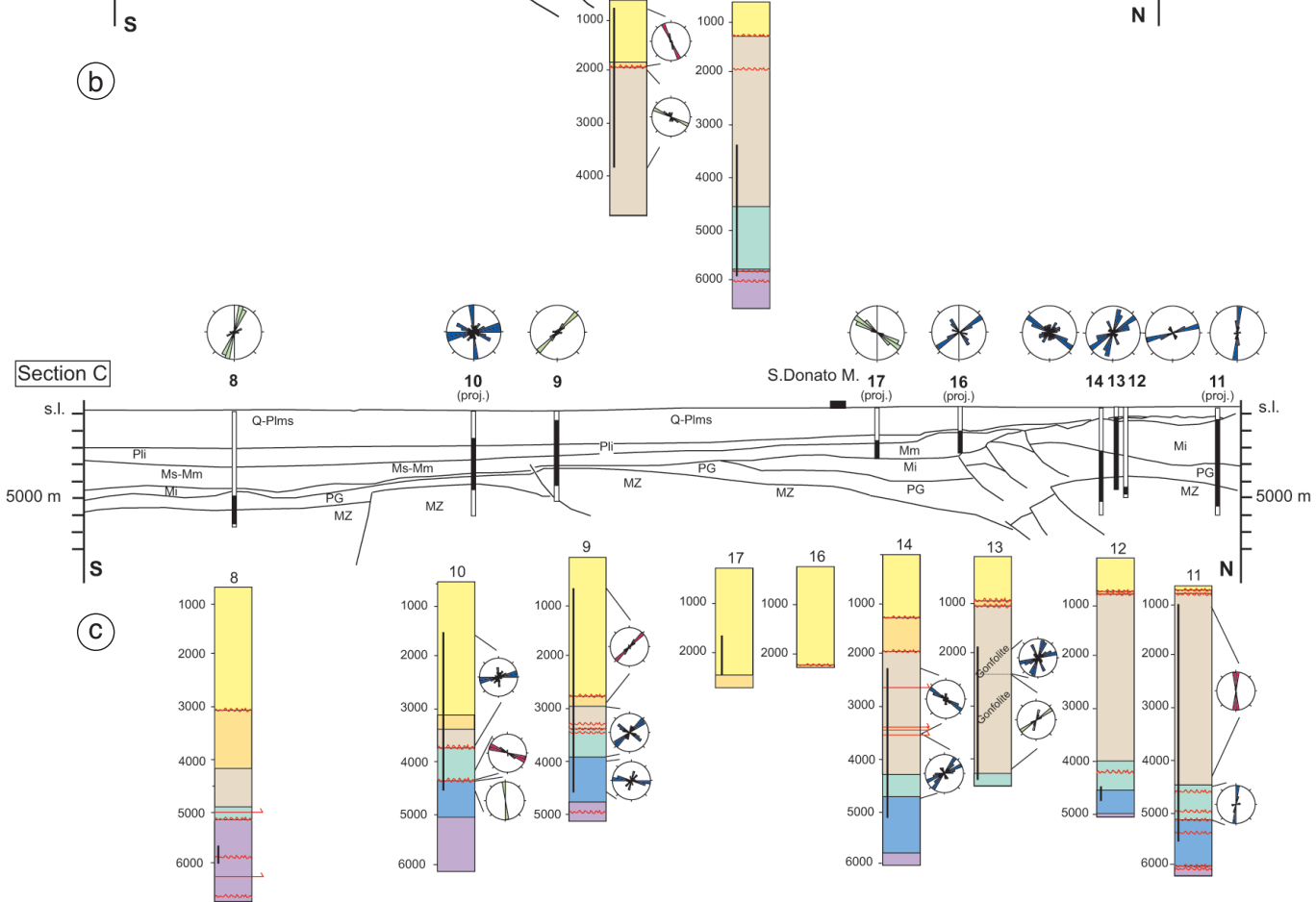

Fig. 5b,c. Two sections (b, c) across the study area (see fig. 2 for locations). Well numbers as in figs. 2, 4 and table I; upper rose diagrams like in fig. 4 . The black area along the drillings indicates the analyzed log interval, the black line along the simplified stratigraphic columns corresponds to the breakout depth interval. Rose diagrams beside the stratigraphic section are relative to the specified intervals. For stratigraphic legend of wells see fig. 5a. QPlms =Quaternary-upper medium Pliocene; Pli=lower Pliocene; $\mathrm{Ms}=$ upper Miocene; $\mathrm{Mm}=$ middle Miocene; $\mathrm{Mi}=$ lower Miocene; $\mathrm{PG}=$ Paleogene, $\mathrm{MZ}=$ Mesozoic; $\mathrm{K}=$ Cretaceous; $\mathrm{J}=\mathrm{J}$ urassic; $\mathrm{TR}=$ Triassic. Tectonics simplified from Pieri and Groppi (1981). 


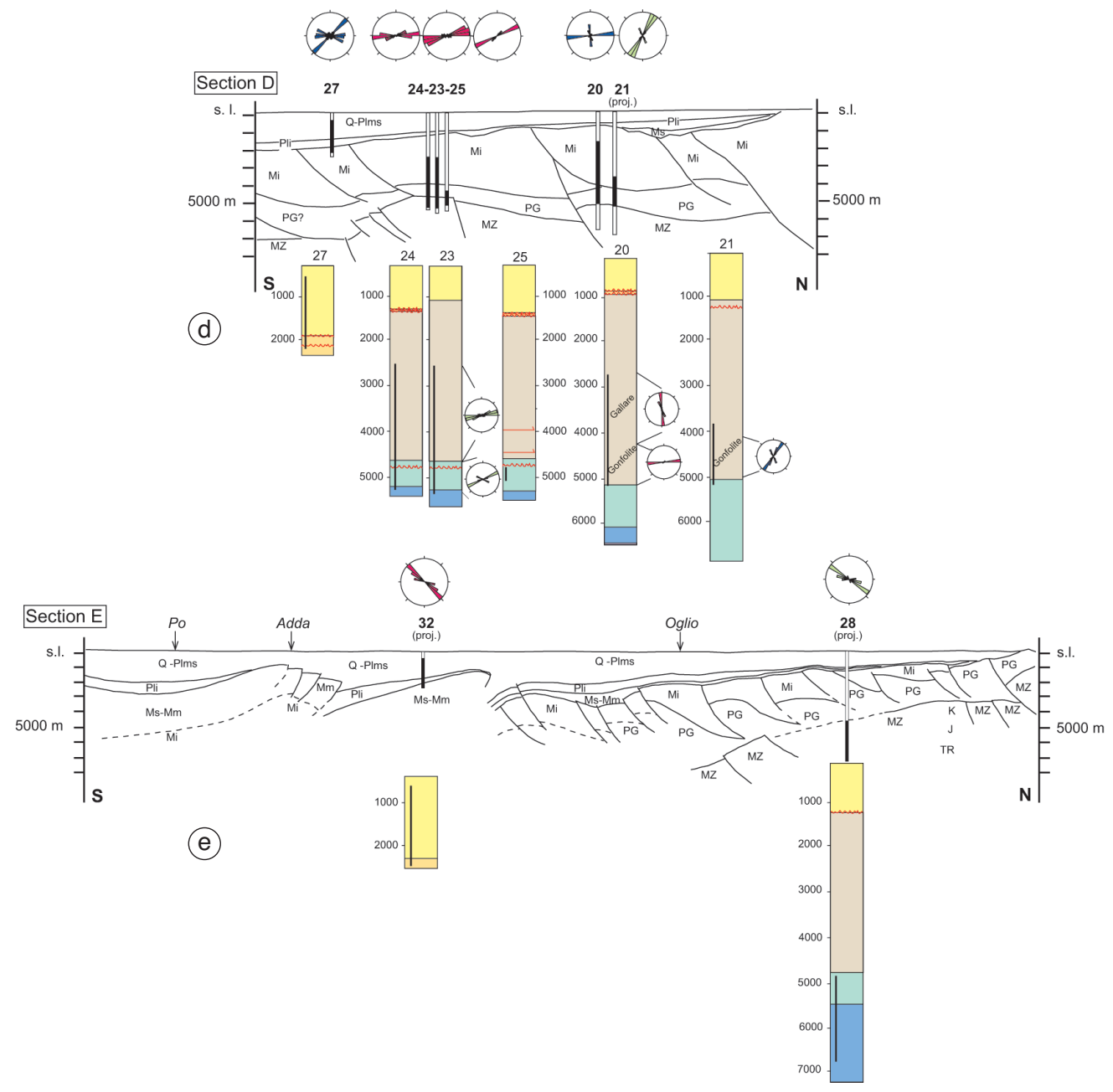

Fig. 5d,e. Two sections (d, e) across the study area (see fig. 2 for locations). Well numbers as in figs. 2, 4 and table I; upper rose diagrams like in fig. 4. The black area along the drillings indicates the analyzed log interval, the black line along the simplified stratigraphic columns corresponds to the breakout depth interval. Rose diagrams beside the stratigraphic section are relative to the specified intervals. For stratigraphic legend of wells see fig. 5a. QPlms = Quaternary-upper medium Pliocene; Pli=lower Pliocene; $\mathrm{Ms}=$ upper Miocene; $\mathrm{Mm}=$ middle Miocene; $\mathrm{Mi}=$ lower Miocene; $\mathrm{PG}=$ Paleogene, $\mathrm{MZ}=$ Mesozoic; $\mathrm{K}=$ Cretaceous; $\mathrm{J}=\mathrm{J}$ Jurassic; $\mathrm{TR}=$ Triassic . Tectonics simplified from Pieri and Groppi (1981).

We have associated the wells in five different groups mainly according to the geological and structural setting and on the basis of stress analysis results (figs. 2 and fig. 4). In the next section we discuss the results for each deep well except data relative to $\mathrm{E}$ quality values. Figure 4 shows $S_{h \text { min }}$ direction for each well and the mean value of $S_{h \min }$ for each identified 
group, computed considering all breakout data. We also performed a detailed analysis in those wells characterized by two $S_{h \text { min }}$ preferential orientations to find possible relationships between breakout directions and geological/tectonic units.

- Group a (see fig. 4) includes 4 wells localized close to the border of south verging structures. This group shows consistent different mean orientation in $S_{h \min }$ directions, except for well no. 5 (quality D) that has a higher scattering of data especially in its bottom part (table I and fig. 5a). Well no. 1 (quality B) gives the best result in terms of standard deviation probably because breakout intervals are deeper and in the carbonatic units. In well no. 2 (quality C) two slightly different breakout directions occur in distinct lithologies (fig. 5b). One main direction is $\mathrm{N} 310 \pm 24^{\circ}$ relative to the deepest well portion, in the Gonfolite and Gallare Formations (Eocene-Upper Miocene), whereas, the other direction $\left(\mathrm{N} 335 \pm 15^{\circ}\right)$ is found in the mainly clayey-sandy Messinian-Pleistocene Formations. Well no. 3 (quality C) also shows different breakout directions but they are referred to the same stratigraphic interval ( 2200-3500m). For this Group, considering only the best data for the wells of quality A, B and C (breakout length $2121 \mathrm{~m}$ ) we obtained a mean $S_{h \min }$ direction N314 $\pm 19^{\circ}$ (fig. 4).

- Group b (see fig. 4) includes wells located in the middle of the Po Plain between the south and north verging structures of Alps and Apennines, respectively. It contains six very deep boreholes (between 4960 and $6750 \mathrm{~m}$ ), with quality $\mathrm{C}, \mathrm{D}$, and $\mathrm{E}$ ( 2 wells were discarded). The remaining four wells show a coherent $S_{h \min }$ direction (about NE-SW oriented), except well no. 10 that displays a high dispersion of directions. Drilling no. 10 (quality D) is characterized by three main breakout directions with a $\mathrm{N} 83 \pm 36^{\circ} S_{h \min }$ average orientation. For this reason we have plotted three rose diagrams for different depth intervals. In the deepest part of the well (between 4440 and 4590 m, in Lias-Dogger carbonatic sequence), an about NS orientation is found, relative to very few data (fig. 5c). Data from the Upper Jurassic-Eocene pelagic units (second plot) have a mean direction N297 $\pm 14^{\circ}$ over an analysed interval between 3990 and
$4330 \mathrm{~m} . \mathrm{N} 295 \pm 32^{\circ}$ is the breakout orientation from the third plot, relative to the depth interval 1563-3650 m where clayey-sandy lithologies (Upper Miocene-Plio-Quaternary) are crossed. We also analysed in detail well no. 9 (quality C) that shows a mean $\mathrm{N} 51 \pm 26^{\circ} S_{h \text { min }}$ orientation. Three plots were performed for this well (fig. 5c). The first plot is relative to the Lias-Dogger carbonatic sequence $(3875-4525 \mathrm{~m})$ yielding a $S_{h \text { min }}$ orientation N89 $\pm 19^{\circ}$ for 238 m of breakout length. The second plot points out a N64 \pm $\pm 33^{\circ} S_{h \text { min }}$ direction for $303 \mathrm{~m}$ of breakout length in the depth interval between 2900 and 3800 . The third plot, relative to the Plio-Quaternary units, shows a mean breakout orientation $\mathrm{N} 49 \pm 19^{\circ}$ for $1172 \mathrm{~m}$ of breakout length. For this Group, considering only the best data for the wells of quality C we obtained a mean $S_{h \text { min }}$ direction $\mathrm{N} 56 \mathrm{E} \pm 27^{\circ}$ (fig. 4 ).

- Group c (see fig. 4) is relative to 13 boreholes (wells no. 12 to 17 ; no. 22 to 28 ) that show different $S_{h \min }$ orientations. Only two wells have quality $\mathrm{E}$ (15 and 22) and six wells (12, 13, 14, 16,26 and 27) show rose diagrams characterized by highly scattered data. Wells (no. 23-25) relative to an important gas field are characterized by good quality data with $S_{h \min }$ orientation about EW. The same mean orientation is recognized also in wells no. $27\left(\mathrm{~N} 81 \pm 33^{\circ}\right)$ and no. 28 $\left(\mathrm{N} 296 \pm 16^{\circ}\right)$. The detailed analysis performed in some wells (fig. 5c) did not clarify the reasons for the scattered $S_{h \min }$ directions. For this Group, considering only the best data for the wells of quality A, B and C we obtained a mean $S_{h \min }$ direction $\mathrm{N} 85 \mathrm{E} \pm 21^{\circ}$ (fig. 4 ).

- Group d (see fig. 4) is relative to seven boreholes (wells no. 11, 18-21, 29, 30) located in the south verging alpine structures. The best quality wells are characterized by breakout orientations almost NS whereas well no. 20 (D quality) shows an EW trend. From a detailed analysis (fig. 5a,d) the NS $S_{h \min }$ orientation characterizes the shallowest depth intervals, whereas few breakout data from the deepest part are about EW trending (wells no. 18 and no. 20). For this Group, considering only the best data for the wells of quality B and C we obtained a mean $S_{h \text { min }}$ direction N27E $\pm 33^{\circ}$ (fig. 4).

- Group e (see fig. 4) includes five boreholes (no. 31-35) with consistent $S_{h \min }$ orienta- 


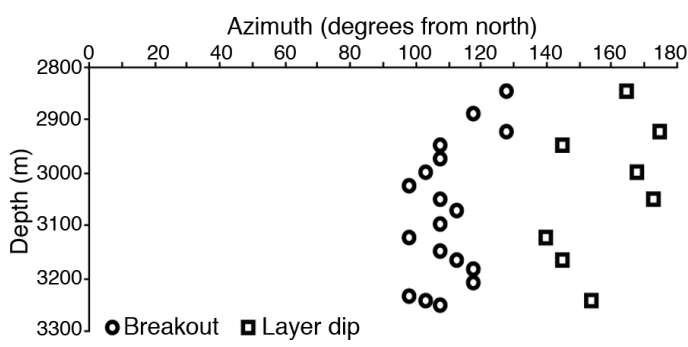

Fig. 6. Comparison between breakout azimuth and layer dip: example relative to well no. 34 . When the two data set have different azimuth at the same depth, the detected breakout zone is true as its orientation is not influenced by the bedding planes.

tions. One well is A quality, two are B and two wells have been discarded. Due to the good data quality, detailed breakout analysis in the different geological units was performed only in well no. 35 which has the greatest standard deviation value. Breakout orientations are very good in the Gallare formation and more scattered within the (shallower) Gonfolite formation (fig. 5a). For this group, considering only the best data for the wells of quality A and B we obtained a mean $S_{h \text { min }}$ direction N294 $\pm 12^{\circ}$ (fig. 4).

Finally, the easternmost well (no. 36; fig. 2) has a high dispersion of data. In detail, it shows $\mathrm{N} 40 \pm 13^{\circ} S_{h \text { min }}$ orientation along the $214 \mathrm{~m}$ of analyzed $\log$ in the deepest formation (Triassic sequence) and heterogeneous $S_{h \min }$ directions in the lower-middle Lias and in the Plio-Quaternary units.

For the whole set of wells in the region, we performed a comparison between breakout azimuth and layer dip to determine if the logging tool followed an enlargement due to bedding planes instead of a real breakout zone. In the 13 wells where the comparison was possible, the borehole breakout orientations are never parallel to the layer dip confirming that they are due to the present-day stress field (regional or local) action, making our results and interpretations more confident (fig. 6).

Moreover, we analyzed breakouts in the different sedimentary units and did not find any systematic orientation referred to the upper sequences (Plio-Pleistocene) or the deeper ones.

\section{Discussion}

In this section we discuss the results of breakout analysis with respect to the thrusts tectonic structures that in this area are complicated by the presence of strike-slip faults. In order to define the relations between active stress orientations and structures we use cross-sections of fig. 5a-e oriented both $\sim \mathrm{E}-\mathrm{W}$ and $\sim \mathrm{N}-\mathrm{S}$ (see location in fig. 2).

The strong variability in stress orientations is well shown along section A (fig. 5a) even if this section is not very meaningful to explain the relationships between breakouts and the regional structural setting. In fact, section A runs E-W through the Po Plain, about parallel to the main structural trends.

In the western sector an about NW-SE $S_{h \min }$ orientation was detected in three wells (no. 1-23 , fig. 4) at different depths and in different geological units (table I). We can explain this orientation considering these data with respect to section B (fig. 5b): it runs $\sim \mathrm{N}-\mathrm{S}$, from the south-verging Alpine structures to the Central Po Plain, where the flat Plio-Quaternary sediments reach more than $5 \mathrm{~km}$ depth. These wells cross the structures related to the outer front of Southern Alps domain (fig. 5b); their $S_{h \min }$ orientations are about perpendicular to the close main structures (fig. 7) pointing out a possibly normal faulting tectonic regime. We can hypothesize that the thrust front is no longer active, at least in this portion, as also suggested by Mariucci and Müller (2003) where a method that compares breakout occurrence and rock strength assigned a normal faulting regime to well no. 1.

The apparent difference in the breakout directions in the central part of the section A (fig. 5a) can be explained from the observation of the location map (fig. 2) as the wells no. 11-1819 and no. 12-13-23-24-25 are located northward and southward of the section respectively. In this context the directions are consistent in both groups: about $\mathrm{N}-\mathrm{S}$ in the former and from ENE to EW in the latter. An explanation of these two different $S_{h \min }$ directions (NS and EW) can also be deduced from sections $\mathrm{C}$ and $\mathrm{D}$, drawn perpendicular to the main tectonic structures (fig. 5c,d). The wells located nearest 


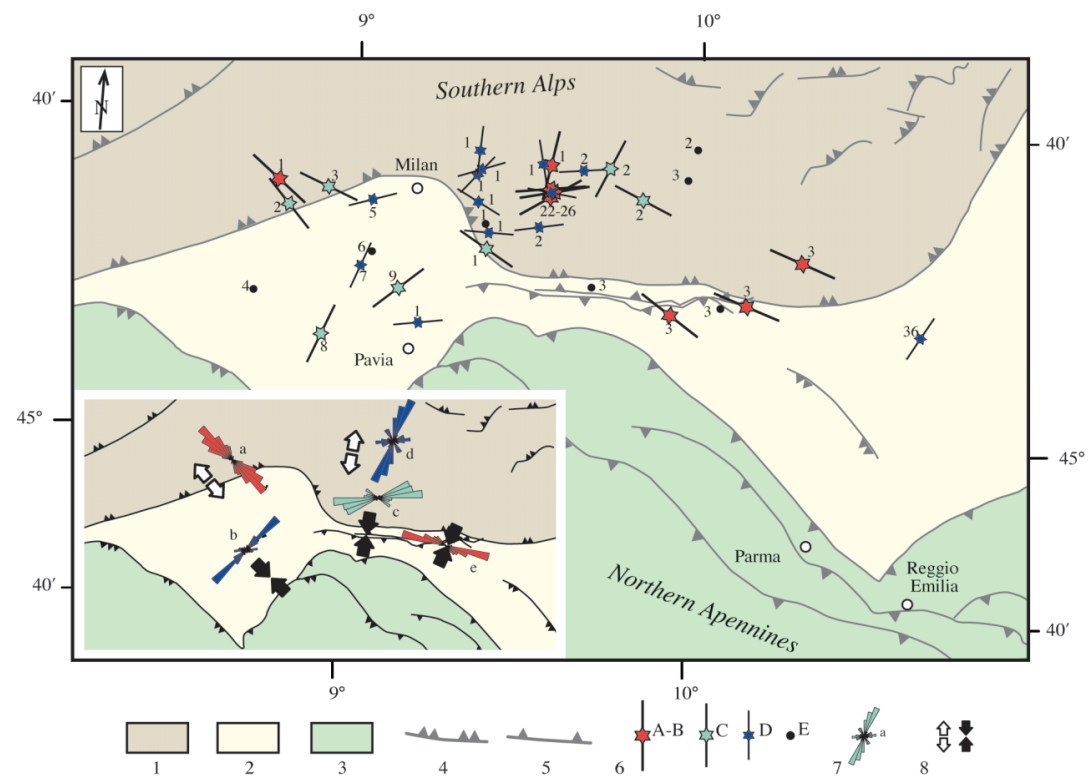

Fig. 7. $S_{h \min }$ orientations from borehole breakout analysis compared to the tectonic structures. 1 - Southern Alps tectonic units; 2 - Po Plain-Adriatic foreland; 3 - Apennines tectonic units; 4 - Pre-Middle Pliocene thrusts; 5 - Middle Pliocene-Pleistocene thrusts; 6 - $S_{h \min }$ directions and well quality ranks; 7 - Rose plot of $S_{h \min }$ directions of well groups indicated by the letter (see fig. 4) where different colours stand for quality as in point 6; 8 - estimated tectonic regimes: extension and compression respectively. Tectonics modified from Pieri and Groppi (1981) and CNR-PFG (1991).

to the thrust front show an E-W $S_{h \text { min }}$ direction parallel to it (fig. 5d) indicating a probably active compression, while a N-S $S_{h \text { min }}$ direction seems to be confined farther from the thrust front (figs. 5c and 7) indicating a possible active extension. Another reason for these two $S_{h \min }$ directions can be found in the different depths where the breakouts are recognized: N$\mathrm{S}$ trend can be explained by an active extension in the shallow part of the structures (i.e. wells no. 18,19 and 20), whereas an E-W trend is predominant in their deep part (i.e. well no. 18, $20,23,25)$ suggesting active compression (fig. $5 \mathrm{a}, \mathrm{d})$. In the southernmost part of section $\mathrm{C}$ (wells no. 8 and no. 9 in fig. 5c), wells with a prevalent $S_{h \min }$ directions NE-SW oriented (fig. 7) are located where thrust structures meet with an undeformed zone. The results agree both with a possibly active Emilia Arc ( $S_{h \min }$ directions parallel to the west side of this arc) and with a not active Monferrato Arc $\left(S_{h \text { min }}\right.$ direc- tions perpendicular to its eastern side). A unique interpretation is difficult because the wells are located far from both the arcs and because these are the only available data.

Toward the east there are a few wells (fig. $5 \mathrm{a}, \mathrm{e})$ characterized by a prevailing WNW-ESE $S_{h \text { min }}$ direction (wells no. $28,32,34,35$; fig. 7). Some boreholes (no. 32, 34, 35) are close to main thrust structures $\sim \mathrm{E}-\mathrm{W}$ trending belonging to the outer fronts of Apennines and to the Southern Alps; the inferred $S_{h \min }$ direction can be related to a NNE oriented active compression suggesting a present-day activity of $\sim \mathrm{E}-\mathrm{W}$ thrusts, as also evidenced by Benedetti et al. (2003). Recent studies mainly based on geomorphological data (Burrato et al., 2003) suggest an E-W oriented seismogenic source for one of the main historical earthquakes which occurred in 1802 (fig. 3). This seismogenic structure (named Orzinuovi) corresponds to a blind thrust E-W oriented, $30^{\circ}$ north dipping 
extending from 3 to $6 \mathrm{~km}$ of depth. In the same way, this $S_{h \min }$ orientation matches the average orientation (fig. 7) of this area and then it is representative of the regional stress field (Montone et al., 2004).

Inside an active thrust structure it is possible to identify a change in stress regime from compressive in its frontal part and extensive in the central part (Ramsay, 1967), thus with $S_{h \min }$ directions oriented parallel and perpendicular to the structure, respectively. In our discussion we often refer to this scheme even if a further complexity in the stress orientations is due to the presence of strike-slip structures, mainly located along the lateral ramps of the buried thrusts but also along the Southern Alpine domain (Pieri and Groppi, 1981; Piana, 2000; Benedetti et al., 2003; Costa, 2003). In some cases it has been observed that if active structures cross a well the detected stress directions are influenced; on the contrary if the borehole is quite far from active faults the breakout directions are due only to the main stress field (Bell et al., 1992; Barton and Zoback, 1994; Mariucci et al., 2002). Geodetic data indicate a N-S compression across the Central and Eastern Alps and an E-W extension in the Western Alps (Nocquet and Calais, 2003), in agreement with the strain regime deduced from the seismicity (Eva et al., 1997; Sue et al., 1999). However, according to other authors the presentday strain field in the Western Alps and the Western Po Plain shows no significant deformation (Caporali et al., 2002; Serpelloni et al., 2005). From a seismotectonic point of view, the great variability of stress field can be explained by the few and relatively small earthquakes that usually occur in the area, probably related to the movements of small active structures that accommodate the regional stress, following very different orientations often inherited from the complex past tectonic history. Inferring the regional stress field only from the in situ stress measurements is often difficult since they may reflect the local stress, sometimes very different in orientation from the regional one. On the other hand, also the single well result that we interpret as regional trend can be a local orientation similar to the regional one only by chance. All these factors hinder any interpretation of the future earthquake style of the area. However, as independent data
(Benedetti, 2003; Burrato, 2003) indicate that the thrust structures with prevailing E-W strike are still active, also following our results reverse faulting and subordinately strike slip earthquakes of small size are the most probable.

\section{Conclusions}

A detailed breakout analysis has been performed in 36 deep wells of the Lombardy Region, using paper and digital logs to depict the pattern of stress field orientations in an area where few active stress data are available.

In this sector of the Po Plain the south verging Alpine tectonic units face the north verging Apenninic ones and, because of the huge amount of Plio-Quaternary units that cover them and the low seismicity level, it is difficult to understand the complex relationships between the two belts and the present-day state of stress. In this context, active stress data from boreholes can provide useful information to determine the possible activity of the buried thrust fronts.

The results, in terms of $S_{h \min }$ directions, show a very complex pattern characterized by inhomogeneous orientations related to a not uniform stress field. The structural setting of the area consists of arc shaped thrusts and the results partly reflect this geometry. Unlike what was observed eastward, along the Ferrara-Romagna Arc (Montone and Mariucci, 1999) where $S_{h \min }$ orientations follow the curvature of the buried arc more clearly, here these variations are less evident probably because of the distance of the boreholes from the active thrust front, both horizontally and at depth. Many borehole breakouts located quite far from the structures reflect the regional stress field, here characterized by $S_{h \min }$ directions from about WNW-ESE to E-W, related to the general $\sim \mathrm{N}-\mathrm{S}$ compression observed along the border of the Adriatic foreland (Montone and Mariucci, 1999; Selvaggi et al., 2001; Benedetti et al., 2003; Burrato et al., 2003; Costa, 2003; Montone et al., 2004; Viti et al., 2004). Although strain regime still remains to be clearly established in the Alps (Nocquet and Calais, 2003), our results point to a general compression in NNE-SSW direction, broadly 
in agreement with geodetic data. Moreover, this work contributes to explain the local $S_{h \min }$ orientations that we believe linked to the presence of minor active structures deflecting the regional stress.

\section{Acknowledgements}

We are very grateful to Eni SpA for providing borehole data and permission for publication. Many thanks are due to the two referees for their thorough reviews and helpful suggestions that greatly improved the paper.

\section{REFERENCES}

ANDERSON, H.J. and J.A. JACKSON (1987): Active tectonics of the Adriatic region, Geophys. J. R. Astrophys. Soc., 91, 937-983

BARTON, C.A. and M.D. ZoBACK (1994): Stress perturbations associated with active faults penetrated by boreholes: possible evidence for near-complete stress drop and a new technique for stress magnitude measurement, J. Geophys. Res., 99 (B5), 9373-9390.

Bell, J.S. and D.I. Gough (1979): Northeast-southwest compressive stress in Alberta: evidence from oil wells, Earth Planet. Sci. Lett., 45 (2), 475-482.

Bell, J.S., G. Caillet and J. Adams (1992): Attempts to detect open fractures and non-sealing faults with dipmeter logs, in Geological Applications of Wireline Logs, Geol. Soc. Spec. Pubbl., 65, 211-220.

Benedetti, L.C., P. Tapponier, Y. Gaudemar, I. ManiGHETTI and J. VAN DER WOERD (2003): Geomorphic evidence for an emergent active thrust along the edge of the Po Plain: the Broni-Stradella Fault, J. Geophys. Res., 108 (B5), 2238, doi: 10.1029/2001JB001546.

Burrato, P., F. Ciucci and G. Valensise (2003): An inventory of river anomalies in the Po Plain, Northern Italy: evidence for active blind thrust faulting, Ann. Geophysics, 46 (5), 865-882.

Caporali, A., S. Martin and M. Massironi (2002): the present day strain rate field in Italy and surrounding countries as inferred from geodetic data, Boll. Geofis. Teor. Appl., 43 (1-2), 3-21.

Castellarin, A. and G.B. Vai (1986): South alpine versus Po Plain Apenninic arcs, in The Origin of Arcs, edited by F.C. Wezel (Elsevier Science Publishers B.V., Amsterdam), 253-280.

CNR (1986): Neotectonic sketch map of Italy, scale 1:4500000, Mem. Soc. Geol. Ital., 30.

CNR-PFG (1991): Structural model of Italy and gravity map, Quad. Ric. Sci., 114 (3).

Costa, M. (2003): The buried Apenninic arcs of the Po Plain and Northern Adriatic Sea (Italy); a new model, Boll. Soc. Geol. Ital., 122 (1), 3-23.

Dewey, J.F., M.L. Helman, E. Turco, D.H.W. Hutron and
S.D. KNOTT (1989): Kinematics of Western Mediterranean, in Alpine Tectonics, edited by M.P. CowARD, D. Detrich and R.G. PArk, Geol. Soc. Spec. Publ. London, 45, 265-283.

Dziewonski, A.M., G. Ekström, and N.N. MaterNOVSKAYA (2000): Centroid-moment tensor solutions for October-December 1999, Phys. Earth Planet. Int., 121, 205-221.

Eva, E., S. Solarino, C. Eva and G. Neri (1997): Stress tensor orientation derived from fault plane solutions in the Southwestern Alps, J. Geophys. Res., 102 (B4), 8171-8186.

Frepoli, A. and A. Amato (1997): Contemporaneous extension and compression in the Northern Apennines from earthquake fault plane solutions, Geophys. J. Int., 129, 368-388.

Mariucci, M.T. and B. Müller (2003): The tectonic regime in Italy inferred from borehole breakout data, Tectonophysics, 361, 21-35.

Mariucci, M.T., A. Amato, R. GAmbini, M. Giorgioni and P. Montone (2002): Along-depth stress rotations and active faults: an example in a 5-km deep well of Southern Italy, Tectonics, 21 (4), 1021, doi: 10.1029/2001TC001338.

Montone, P. and M.T. Mariucci (1999): Active stress along the NE external margin of the Apennines: the Ferrara Arc, Northern Italy, J. Geodyn., 28, 251-265.

Montone, P., A. Amato and S. Pondrelli (1999): Active stress map of Italy, J. Geophys. Res., 104 (B11), 25595-25610.

Montone, P., M.T. Mariucci, S. Pondrelli and A. Amato (2004): An improved stress map for Italy and surrounding regions (Central Mediterranean), J. Geophys. Res., 109 (B10410), doi: 10.1029/2003JB002703.

NocQueT, J.M. and E. CALAIS (2003): Crustal velocity field of Western Europe from permanent GPS array solutions, 1996-2001, Geophys. J. Int., 154, 72-88.

PEROTTI, C.R. (1991): Osservazioni sull'assetto strutturale del versante Padano dell'Appennino Nord-Occidentale, Atti Ticinensi di Scienze della Terra, 34, 11-22.

PianA, F. (2000): Structural setting of Western Monferrato (Alps-Apennines junction zone, NW Italy), Tectonics, 19 (5), 943-960.

PIERI, M. and G. GropPI (1981): Subsurface geological structure of the Po Plain (Italy), CNR-PF Geodin. Pubbl., 414, pp. 23.

Plumb, R.A. and S.H. Hickmann (1985): Stress-induced borehole elongation: a comparison between dipmeter and the borehole televiewer in the Auburn geothermal well, J. Geophys. Res., 90, 5513-5521.

Pondrelli, S., A. Morelli, G. Ekström, S. Mazza, E. Boschi, and A.M. DzIEwOnski (2002): EuropeanMediterranean regional centroid-moment tensors: 1997-2000, Phys. Earth Planet. Int., 130, 71-101.

RAMSAY, J.G. (1967): Folding and Fracturing (McGrawHill, New York), pp. 568.

Selvaggi, G., F. Ferulano, M. Di Bona, A. Frepoli, R. Azzara, A. Basili, C. Chiarabba, M.G. Ciaccio, F. Di LuCCIO, F.P. LuCENTE, L. MARGHERITI and C. NosTRO (2001): The $M_{w} 5.4$ Reggio Emilia 1996 earthquake: active compressional tectonics in the Po Plain, Italy, Geophys. J. Int., 144, 1-13.

Serpelloni, E., M. Anzidei, P. Baldi, G. Casula and A. GALVANI (2005): Crustal velocity and strain-rate fields 
in Italy and surrounding regions: new results from the analysis of permanent and non-permanent GPS networks, Geophys. J. Int., 161, 861-880, doi: 10.1111/ j.1365-246X.2005.02618.x.

Sue, C., F. Thouvenot, J. Frechet and P. Tricart (1999): Widespread extension in the core of the Western Alps revealed by earthquake analysis. J. Geophys. Res., 104 (B11), 25611-25622.

Viti, M., J. De Luca, D. Babbucci, E. Mantovani, D. AlBARELLO and F. D'ONZA (2004): Driving mechanism of tectonic activity in the Northern Apennines: quantita- tive insights from numerical modelling, Tectonics, 23, TC4003, doi: 10.1029/2004TC001623.

WorkIng Group CPTI (2004): Catalogo Parametrico dei Terremoti Italiani, Versione 2004 (CPTI04), (INGV, Bologna), (on line: http://emidius.mi.ingv.it/CPTI/).

ZoBACK, M.L. (1992): First and second order patterns of stress in the lithosphere: the World Stress Map Project, J. Geophys. Res., 97, 11703-11728.

(received January 3, 2005; accepted July 29, 2005) 